\title{
GENETIC DIVERSITY OF Picea orientalis (L.) LINK POPULATIONS IN TURKEY
}

\section{GENETSKA RAZNOLIKOST POPULACIJA Picea orientalis (L.) LINK U TURSKOJ}

\author{
Deniz GÜNEY' ${ }^{1}$ Zeki YAHYAOǦLU ${ }^{1}$, Ali BAYRAKTAR ${ }^{1}$, Fahrettin ATAR ${ }^{1 *}$ and İbrahim TURNA ${ }^{1}$
}

\begin{abstract}
Summary
Knowledge of genetic variation is needed to understanding the genetic structure in forest tree populations. In addition, the determination of the genetic structure in the natural distribution areas of forest trees has become easier depending on the development of the isoenzyme technique. Determining the genetic structure and variations of Picea orientalis (L.) Link, which is limited local natural distribution areas on the world, transfer of this genetic to the future generations with sustainable forestry is important to ensure the continuity of the species. In this study, genetic differences and similarities were determined for P. orientalis populations in selected regions (Artvin, Torul-Örümcek, Tirebolu-Akılbaba, Ordu-Çambaşı, Artvin-Șavşat, Ardanuç-Ovacık, Şavşat-Sahara, Artvin-Saçinka, Ardahan-Posof and Maçka-Hamsiköy) in Turkey. In the study using 10 gene loci in different enzyme systems to determine the genetic variation, the values of heterozygosity $\left(H_{o}\right)$, number of alleles per locus $\left(A_{L}\right)$, genetic diversity (v), intrapopulational differentiation $\left(\mathrm{d}_{\mathrm{T}}\right)$, multilocus diversity $\left(\mathrm{V}_{\mathrm{gam}}\right)$ and differentiation among populations $(\mathrm{Dj})$ were determined in these populations. The grand means were obtained as $0.154,1.74$ and 1.719 for the observed heterozygosity, alleles per locus and genetic diversity, respectively. Moreover, when the genetic diversity was considered, three different groups arose in terms of selected populations. Since Torul-Örümcek population had relatively higher results in contrast to other populations, this population has high importance for sustainability of gene resource of oriental spruce.
\end{abstract}

KEY WORDS: Genetic diversity, conservation, Isoenzyme, Picea orientalis,

\section{INTRODUCTION}

\section{UVOD}

Picea orientalis (L.) Link (oriental spruce) spreads over North-East Anatolia and in adjacent region of the Caucasus. The whole area of its present distribution has a North to South extensions from $43^{\circ} 50^{\prime} \mathrm{N}$. to $40^{\circ} 23^{\prime} \mathrm{N}$., and East to West extensions from $44^{\circ} 13^{\prime} \mathrm{E}$. (Greenwich) to $37^{\circ} 47^{\prime} \mathrm{E}$., this area is horseshoe-shaped in outline and is part of the mountainous vegetation zones. The high mountain chains have a great modifying influence on the climate and on the vegetation throughout all the area. P. orientalis covers parts of the big Caucasus Mountains, covering the Giorgi and
Tiflis regions, the small Caucasus Mountains, and the Pontus range in North-East Anatolia. Spread to the South-East is prevented by the arid climate of the hinterland. Further limitations are evident by the Black Sea and by mountain chains, except in the West near the Melet River where $P$. orientalis is restricted westwards of the River by dense beech forest. In vertical direction, it begins at the coastal zone and continues as high as $2400 \mathrm{~m}$ altitude (Saatçioğlu 1976; Kayacık 1980; Atalay 1984).

Oriental spruce, paleo endemic tree species (Yahyaoğlu et al. 1991), is one of the most important tree species for Turkey. In addition, this species plays a significant role for the

\footnotetext{
Assoc. Prof. Dr. Deniz Güney, Prof. Dr. Zeki Yahyaoǧlu, Msc. Ali Bayraktar, Dr. Fahrettin Atar, Prof Dr. Ibrahim Turna, department of Forest Engineering, Karadeniz Technical University, 61080 Trabzon, Turkey

*Corresponding author: fatar@ktu.edu.tr
} 
country in terms of ecological and silvicultural aspects. Natural distribution ranges of oriental spruce are between 550 and $2400 \mathrm{~m}$ and it is widespread in the Eastern Black Sea Region, the center of its distribution areas. On the other hand, the species is dominant at treeline and upper subalpine forest, the elevation of this zone varies between 1800 and $2400 \mathrm{~m}$ depending on anthropogenic pressure and local ecological conditions in its natural distribution area (Üçler et al. 2001; Üçler et al. 2018). However, a small number of studies were conducted on genetic variation of oriental spruce. In a study about morphological characters of $P$. orientalis in Turkey, it was determined that the main reason of seed, cone and wing size variation was ecological differentiation throughout gradients, especially regarding watershed parameters and altitude (Turna 2004). In another study performed in $P$. orientalis, genetic variation was attempted by using only two enzyme systems (Turna and Yahyaoğlu 2002). Results of genetic monitoring in populations concerning the species were rare. Goncharenko et al. (1996) stated that heterozygosities and genetic diversities of $P$. orientalis clearly fell below the average.

For sustainable forest health, genetic diversity provides evolutionary potential against a changing environment. As trees are normally the key element of forest ecosystems, their genetic diversity has also special importance. At the same time, it is known that genetic variability is the basis for tree breeding. Thus, the genetic diversity of trees can be seen as the primary factor for forest sustainability and ecosystem stability. Allozymes and molecular markers (Avise 1994; Ouborg 1999) based on DNA can assist in the estimation of genetic diversity, in the development of sustainable forest management practices as genetic, in the determination of genetic structure and diversity of populations (Luo et al. 2005).

Although genetic diversity has been predominantly predicted by DNA markers over the last decade, allozyme still remain a preferred marker due to a number of advantages.
These indicators, which demonstrate the genetic diversity between individuals and populations, are necessary for the development of effective strategies for sustainable management and protection (Crawford 1989; Hamrick et al. 1992; Vicario et al. 1995; Luo et al. 2005; Radu et al. 2014). In addition, the allozyme markers are useful for monitoring the genetic changes in the evolutionary process and for identifying geographic variation models that are useful in gene conservation.

Monitoring the geographical genetic variation within natural populations of $P$. orientalis in Turkey consists of the aim of the present study. In this way, it can be provided a contribution to the characterization of genetic resources and to the practical measures for in-situ conservation of genetic variation. A check on genetic erosion and inbreeding will help to detect genetic loads and thus to avoid destabilization following the use of unqualified forest reproductive material.

\section{MATERIALS AND METHODS MATERIJALI I METODE}

In the scope of this study, seeds were collected from 10 different populations (to be at least 20 trees per population) of oriental spruce. Haploid endosperms and diploid embryos of the air-dry seeds of oriental spruce were used in isoenzyme analysis. Sampling in 10 populations of this species a smaller amount of material was available so that routinely only 60 samples per stand were genotyped, i.e. endosperm and embryo of each of 30 seeds. The geographical coordinates of selected populations of oriental spruce naturally grown in Turkey (Table 1) and distribution on the map, determined by using management plans belong to the country, (Figure 1) are given in below. The geographic distribution of sampled populations allowed an evaluation of overall genetic diversity of this species in Turkey.

Table 1. Elemetar data and elevations related to the populations Tablica 1. Temeljni podaci i nadmorske visine populacija

\begin{tabular}{|c|c|c|c|c|}
\hline $\begin{array}{l}\text { No } \\
\text { Broj }\end{array}$ & $\begin{array}{l}\text { Provenance } \\
\text { Provenijencija }\end{array}$ & $\begin{array}{c}\text { Latitude } \\
\left({ }^{\circ}, ', "\right) \\
\text { Zemljopisna. širina }\end{array}$ & $\begin{array}{c}\text { Longitude } \\
\left({ }^{\circ}, ', ",\right) \\
\text { Zemljopisna dužina }\end{array}$ & $\begin{array}{l}\text { Altitude (m) } \\
\text { Visina }\end{array}$ \\
\hline 1 & Artvin & $41^{\circ} 09^{\prime} 46^{\prime \prime}$ & $41^{\circ} 47^{\prime} 57^{\prime \prime}$ & 1150 \\
\hline 2 & Torul-Örümcek & $40^{\circ} 40^{\prime} 29^{\prime \prime}$ & $38^{\circ} 58^{\prime} 01^{\prime \prime}$ & 1700 \\
\hline 3 & Tirebolu-Akılbaba & $40^{\circ} 41^{\prime} 32^{\prime \prime}$ & $38^{\circ} 54^{\prime} 32^{\prime \prime}$ & 1850 \\
\hline 4 & Ordu-Çambaşı & $40^{\circ} 38^{\prime} 08^{\prime \prime}$ & $37^{\circ} 53^{\prime} 55^{\prime \prime}$ & 1640 \\
\hline 5 & Artvin-Şavşat & $41^{\circ} 14^{\prime} 08^{\prime \prime}$ & $42^{\circ} 22^{\prime} 13^{\prime \prime}$ & 1265 \\
\hline 6 & Ardanuç-Ovacık & $40^{\circ} 58^{\prime} 54^{\prime \prime}$ & $42^{\circ} 02^{\prime} 04^{\prime \prime}$ & 1920 \\
\hline 7 & Şavşat-Sahara & $41^{\circ} 13^{\prime} 49^{\prime \prime}$ & $42^{\circ} 26^{\prime} 59^{\prime \prime}$ & 1900 \\
\hline 8 & Artvin-Saçinka & $41^{\circ} 11^{\prime} 06^{\prime \prime}$ & $41^{\circ} 55^{\prime} 29^{\prime \prime}$ & 2014 \\
\hline 9 & Ardahan-Posof & $41^{\circ} 29^{\prime} 52^{\prime \prime}$ & $42^{\circ} 44^{\prime} 00^{\prime \prime}$ & 1370 \\
\hline 10 & Maçka-Hamsiköy & $40^{\circ} 38^{\prime} 30^{\prime \prime}$ & $39^{\circ} 22^{\prime} 54^{\prime \prime}$ & 1810 \\
\hline
\end{tabular}



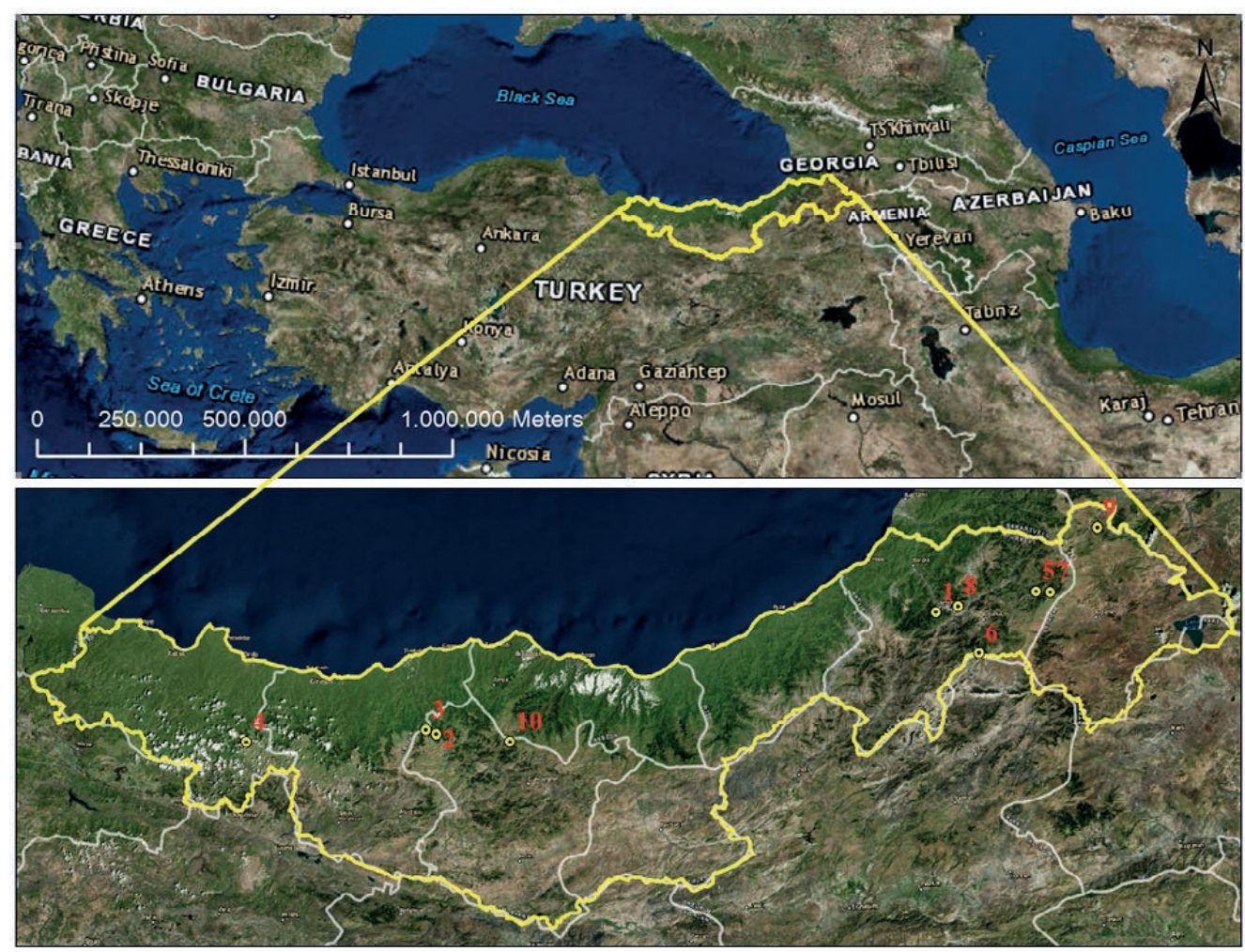

Figure 1. Natural distribution areas of Picea orientalis in Turkey and locations of sampled populations Slika 1. Prirodno rasprostiranje Picea orientalis u Turskoj i lokaliteti uzorkovanih populacija

Table 2. Survey of enzyme sistem and polymorphic gene loci Tablica 2. Pregled enzimskih sustava za polimorfne genske lokuse

\begin{tabular}{|c|c|}
\hline $\begin{array}{c}\text { Enzyme system and } \\
\text { Enzyme Commission number (EC) } \\
\text { Enzimski sustav i enzimski broj (EC) }\end{array}$ & $\begin{array}{l}\text { Studied gene loci } \\
\text { Istraživani genski lokusi }\end{array}$ \\
\hline $\begin{array}{l}\text { Aspartate aminotransferase } \\
\text { (AAT syn. GOT), EC 2.6.1.1 } \\
\text { Aconitase (ACO), } \\
\text { (ACO) EC 4.2.1.3 } \\
\text { Alcohol dehydrogenase } \\
\text { (ADH) EC 1.1.1.1 }\end{array}$ & $\begin{array}{l}\text { AAT-A } \\
\text { ACO-A }\end{array}$ \\
\hline $\begin{array}{l}\text { Glutamate dehydrogenase } \\
\qquad(\mathrm{GDH}) \mathrm{EC} \text { 1.4.1.2 }\end{array}$ & GDH-A \\
\hline $\begin{array}{l}\text { Isocitrat dehydrogenase } \\
\text { (IDH) EC 1.1.1.42 }\end{array}$ & IDH-B \\
\hline $\begin{array}{l}\text { Leucin aminopeptidase } \\
\text { (LAP) EC 3.4.11.1 }\end{array}$ & LAP-B \\
\hline $\begin{array}{l}\text { Malat dehydrogenase } \\
\text { (MDH) EC 1.1.1.37 } \\
\text { Menadion reductase } \\
\text { (MNR) EC 1.6.99.2 }\end{array}$ & \\
\hline $\begin{array}{c}\text { 6-Phosphogluconate dehydrogenase } \\
\text { (6-PGDH) EC 1.1.1.44 }\end{array}$ & 6-PGDH-A \\
\hline $\begin{array}{l}\text { Phosphoglucose isomerase } \\
\text { (PGI) EC 5.3.1.9 }\end{array}$ & PGI-B \\
\hline $\begin{array}{l}\text { Phosphoglucomutase } \\
\text { (PGM) EC 2.7.5.1 }\end{array}$ & PGM-B \\
\hline $\begin{array}{l}\text { Shikimate dehydrogenase } \\
\text { (SKDH) EC 1.1.1.25 }\end{array}$ & SKDH-A, -B \\
\hline $\begin{array}{l}\text { Number of studied loci } \\
\text { Broj istraživanih lokusa }\end{array}$ & 10 \\
\hline
\end{tabular}

Embryo and megagametophyte were homogenized in 0.08-0.1 M Tris-HCI buffer with $\mathrm{pH}$ 7.5. Other compounds added were: $5 \mathrm{~g}$ saccharose, $150 \mathrm{mg}$ DTT and $3 \mathrm{~g}$ PVP in $100 \mathrm{ml}$ of buffer. Extracts from the megagametophyte and the embryo were positioned adjacent to each other in the gels. Horizontal starch gel electrophoresis (10.5\% starch concentration plus $2.5-3.5 \%$ sucrose) was performed as described by Feret and Bergmann (1976), Conkle et al. (1982) and Liengsiri et al. (1990). The buffer system of Ashton $\mathrm{pH} 8.6$ for GOT and PGM as well as Tris-Citro $\mathrm{pH}$ 7.3 were used as electrode and gel buffers for SKDH, MDH and 6-PGDH. In addition, used enzyme systems and 10 gene loci are listed in Table 2.

Genetic variation within populations is measured by counting the number of alleles or genotypes per gene locus $\left(A_{L}, G_{L}\right)$, with the gene pool diversity in combination with the hypothetical gametic multilocus diversity ( $\left.\mathrm{v}, \mathrm{V}_{\text {gam }}\right)$ (Gregorius 1978; Gregorius 1987) and the intra-populational genetic differentiation $\left(\mathrm{d}_{\mathrm{T}}\right)$ (Gregorius 1987). Heterozygosity is described by the observed proportion $\left(\mathrm{H}_{\mathrm{o}}\right)$ of heterozygotes, fixation coefficients according to Wright (1978). Differences between frequencies of genetic types are statistically tested applying the G-test of homogeneity. In the present study, GSED version 1.1 (Gillet 1998) and BIOSYS-2 (Swofford and Selander 1997) programs were used to calculate the measures. 


\section{RESULTS}

\section{REZULTATI}

Differentiations among populations were evident in respect of heterozygosity, the number of alleles per locus and especially the hypothetical gametic multilocus diversities. Variation parameters including number of trees $(\mathrm{N})$, mean number of alleles and genotypes per locus $\left(A_{L}, G_{L}\right)$, genetic differentiation $\left(\mathrm{d}_{\mathrm{T}}\right)$, observed heterozygosity $\left(\mathrm{H}_{\mathrm{o}}\right)$, expected heterozygosity $\left(\mathrm{H}_{\mathrm{c}}\right)$, fixation index $\left(\mathrm{F}_{\mathrm{is}}\right)$, genetic diversity $(\mathrm{v})$, multilocus diversity $\left(\mathrm{V}_{\text {gam }}\right)$ and differentiation among populations $(\mathrm{Dj})$ related to seed samples of Picea orientalis from 10 different locations in Turkey are examined in Table 3.

\section{Heterozygosity $\left(\mathrm{H}_{0}\right)$ - Heterozigotnost $\left(\boldsymbol{H}_{0}\right)$}

For a particular locus, the observed heterozygosity $\left(\mathrm{H}_{\mathrm{o}}\right)$ is calculated by dividing the number of heterozygous trees with the overall number of the individuals surveyed (Goncharenko et al. 1996). The observed heterozygosity $\left(\mathrm{H}_{\mathrm{o}}\right) \mathrm{va}$ lues ranged between 0.110 (Artvin-Saçinka) and 0.190 (Ordu-Çambaşı), equivalent to a ratio 1:1.72, and the grand mean of 0.154 .

\section{Number Alleles per locus $\left(A_{L}\right)-$ Broj alela po lokusu $\left(A_{\nu}\right)$}

Mean number of alleles per locus is computed by dividing the number of alleles revealed by the overall number of the loci analyzed (Goncharenko et al. 1996). $A_{\mathrm{L}}$ values ranged between 1.70 (Provenance No. 1, 2, 3, 4, 7, 9 and 10) and 1.90 (Provenance No. 6), equivalent to a ratio 1:1.12. In addition, the grand mean was obtained as 1.74 alleles. In the studies on other tree species, this value ranged between 1.60-4.30 for Picea abies (L.) Karst., 1.70-4.70 for Abies alba Mill., 1.50-1.90 for Pinus cembra L., 1.20-2.10 for Pinus halepensis Mill., 1.40-1.60 for Pinus leucodermis Ait., 2.40-3.00 for Pinus nigra Arnold., 2.60-4.30 for Pinus sylvestris L., 1.70-3.20 for Castanea sativa Mill., 2.20-4.00 for Fagus syl- vatica L. and 3.10-3.20 for Quercus petraea Liebl. Moreover, this was determined as 1.90, 2.30, 1.60, 2.70, 2.80 and 3.20 for Larix decidua Mill., Pinus pumila (Pall.) Regel, Pinus sibirica Du Tour, Ficus carica L., Quercus ilex L. and Quercus robur L., respectively (Müller-Starck et al. 1992; MüllerStarck 1995).

\section{Genetic diversity (v) - Genetički diverzitet (v)}

Differences were indicated in terms of the genetic diversity v-values ranges 1.555 (Ordu-Çambaşı) and 1.990 (ArdanuçOvacik), equivalent to a ratio 1:1.279, and the grand mean of 1.719. For each population, the comparison of $A_{L}$ and $v$ values allow to infer tentatively on the mode of frequency distribution of alleles. Samples with similar or identical $A_{L}$ values (e.g. $A_{L}=1.70$ for Provenance No. 1, 2, 3, 4, 7, 9 and 10) can show distinct deviations with respect to the corresponding diversities ( $\mathrm{v}=1.738, \mathrm{v}=1.768, \mathrm{v}=1.709, \mathrm{v}=1.555$, $\mathrm{v}=1.600, \mathrm{v}=1.811$ and $\mathrm{v}=1.730$, respectively). This demonstrates the greater evenness of the allelic frequency distributions of Provenance No. 9 as compared to Provenance No. 1, 2, 3, 4, 7 and 10. In addition, Provenance No. 6 revealed the largest v-value (1.990). On the other hand, it was determined that the second largest $\mathrm{A}_{\mathrm{L}}$ value (1.80) occurred by Provenance No. 5 and 8, but the corresponding low vvalues (1.700 and 1.586, respectively) suggests a larger proportion of rare alleles due to greater deviations from even frequency distribution of alleles (Müller-Starck 1995).

\section{Intrapopulational differentiation $\left(\mathrm{d}_{\mathrm{T}}\right)-$ Intrapopulacijska diferencijacija $\left(d_{T}\right)$}

The trends with respect to the gene diversities were also evident for the gene (allelic) differentiation. Accordingly, while Tirebolu-Akılbaba population gave the largest value $\left(\mathrm{d}_{\mathrm{T}}=0.326\right)$, Ordu-Çambaşı population had the smallest value $\left(\mathrm{d}_{\mathrm{T}}=0.255\right)$. These deviations were equivalent to a ratio of 1:1.278. This ratio was very close with genic diversity

Table 3. Variation parameters in seed samples of the populations Tablica 3. Parametri varijabilnosti u uzorcima sjemena populacija

\begin{tabular}{|c|c|c|c|c|c|c|c|c|c|c|c|c|}
\hline \multirow{2}{*}{$\begin{array}{l}\text { Populations } \\
\text { Populacije }\end{array}$} & \multicolumn{3}{|c|}{$\begin{array}{c}\text { Number } \\
\text { Broj }\end{array}$} & \multicolumn{2}{|c|}{$\begin{array}{l}\text { Diversity } \\
\text { Diverzitet }\end{array}$} & \multirow[t]{2}{*}{$\delta_{\mathrm{T}}$} & \multirow[t]{2}{*}{$\mathrm{H}_{0}$} & \multirow[t]{2}{*}{$\mathrm{H}_{\mathrm{c}}$} & \multirow[t]{2}{*}{$\mathrm{F}_{\text {is }}$} & \multirow[t]{2}{*}{ Div.V } & \multirow[t]{2}{*}{$V_{\text {gam }}$} & \multirow[t]{2}{*}{$\mathrm{Dj}$} \\
\hline & $\mathrm{N}$ & $A_{L}$ & $\mathrm{G}_{\mathrm{L}}$ & Alleles & v & & & & & & & \\
\hline Artvin & 30 & 1.70 & 2.50 & 1.359 & 1.738 & 0.306 & 0.157 & 1.251 & 0.234 & 1.267 & 14.942 & 0.104 \\
\hline T. Örümcek & 30 & 1.70 & 2.40 & 1.398 & 1.768 & 0.301 & 0.114 & 4.960 & 0.443 & 1.280 & 18.077 & 0.058 \\
\hline T. Akılbaba & 30 & 1.70 & 2.50 & 1.343 & 1.709 & 0.326 & 0.153 & 1.533 & 0.270 & 1.274 & 14.710 & 0.086 \\
\hline 0. Çambaşı & 30 & 1.70 & 2.30 & 1.279 & 1.555 & 0.255 & 0.190 & 5.160 & -0.044 & 1.207 & 8.656 & 0.136 \\
\hline A. Şavşat & 30 & 1.80 & 2.60 & 1.326 & 1.700 & 0.275 & 0.153 & 1.836 & 0.111 & 1.224 & 10.971 & 0.067 \\
\hline A. Ovacık & 30 & 1.90 & 2.80 & 1.388 & 1.990 & 0.319 & 0.190 & 5.573 & 0.250 & 1.270 & 16.674 & 0.106 \\
\hline Ş. Sahara & 30 & 1.70 & 2.50 & 1.297 & 1.600 & 0.264 & 0.147 & 2.073 & 0.244 & 1.220 & 9.816 & 0.075 \\
\hline A. Saçinka & 30 & 1.80 & 2.40 & 1.304 & 1.586 & 0.264 & 0.110 & 5.683 & 0.268 & 1.221 & 9.964 & 0.071 \\
\hline A. Posof & 30 & 1.70 & 2.40 & 1.349 & 1.811 & 0.310 & 0.163 & 2.390 & 0.222 & 1.250 & 13.501 & 0.092 \\
\hline M. Hamsiköy & 30 & 1.70 & 2.50 & 1.326 & 1.730 & 0.300 & 0.160 & 5.964 & 0.067 & 1.234 & 11.459 & 0.080 \\
\hline Mean & 30 & 1.74 & 2.49 & 1.337 & 1.719 & 0.292 & 0.154 & 3.642 & 0.207 & 1.245 & 12.877 & 0.088 \\
\hline
\end{tabular}




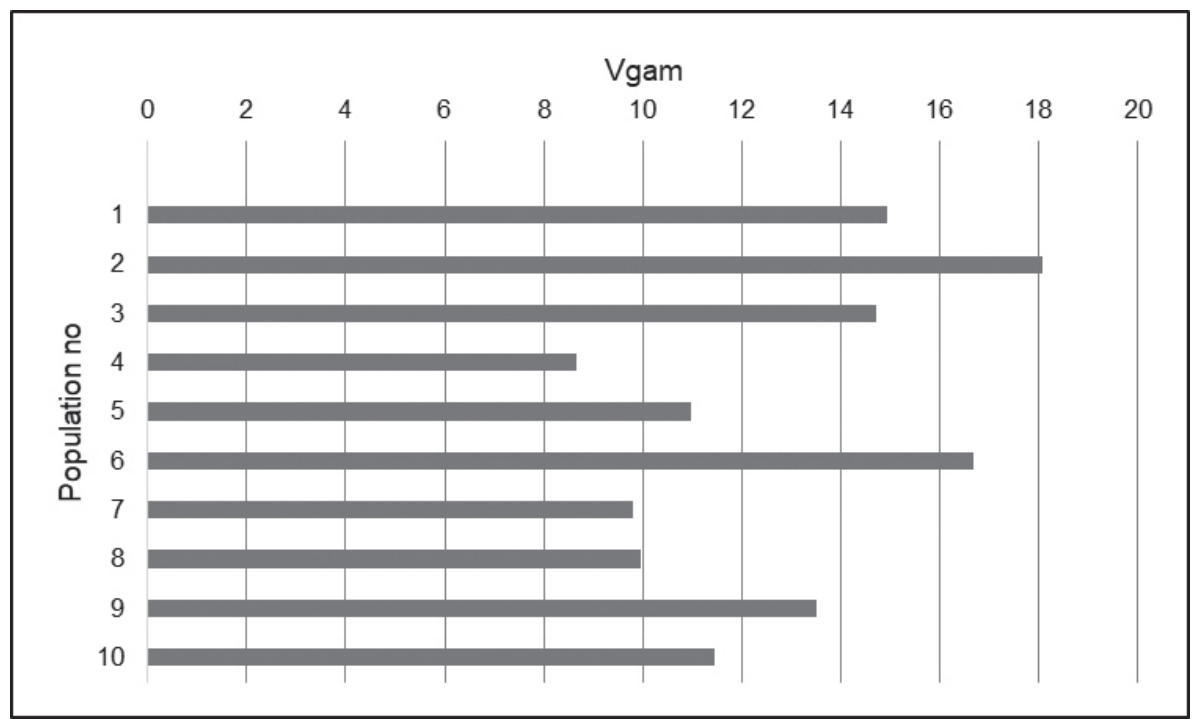

Figure 2. Hypohetical gametic multilocus diversity related to the populations

Slika 2. Hipotetska gametska multilokusna raznolikost populacija

(1:1.279). Thus, it can be understood that discriminative function of the gene differentiation and gene diversity is similar.

\section{Multilocus diversity $\left(\mathrm{V}_{\text {gam }}\right)$ - Multilokusna raznolikost $\left(V_{\text {gam }}\right.$ )}

$\mathrm{V}_{\text {gam }}$ attributes to differences among samples with respect to the genetic diversity. This shows the potential of a set of trees in order to produce genetically different gametes. Thus, genetic variation can submit to the next generation. For autochthonous tree populations, genetic variability is a basic precondition for adaptation and survival in heterogeneous environments (Müller-Starck 1995). This measure is suggested to quantify the ability of forest tree populations to create genetic variation and thus to facilitate adaptation to changing environmental conditions (Gregorius et al. 1986).

As can be seen from Figure 2, there were significant differences among populations. Whereas the maximum $\mathrm{V}_{\text {gam }}$ was obtained as 18.077 in Torul-Örümcek population, the minimum $\mathrm{V}_{\text {gam }}$ was determined as 8.656 in Ordu-Çambaşı population. This was equivalent to a ratio of 1:2.09.

\section{Differentiation among populations (Dj) - Diferencijacija među populacijama (Dj)}

Genetic differentiation among subpopulations is based on genetic distances. Frequencies of genetic types of one population are contrasted with the weighted averages of the frequencies of the remaining populations. Each population is considered as a subpopulation and differentiation is quantified via the genetic distances between one sample and the remaining ones that are pooled as the respective complement population. As a conclusion, genetic differentiation is quantified as a whole (Müller-Starck 1995).
As can be seen from the last column in Table 3, Dj values differentiated considerably from each other: the maximum value occurred in Ordu-Çambaşı population (0.136), the minimum value revealed in Torul-Örümcek population (0.058). This was equivalent to a ratio of 1:2.34. In Figure 3 , the genetic differentiation was illustrated.

Three different groups depending on the gene pool occurred according to the snail diagram used among 10 populations. Ordu-Çambaşı population differentiating from other regions as genetic structure was in a group by itself. Ardanuç-Ovacık and Artvin populations, being genetically close to each other and separating from the other regions, took place in the same group. Another group was formed by Torul-Örümcek, Tirebolu-Akılbaba, Artvin-Şavşat, Şavşat-Sahara, ArtvinSaçinka, Ardahan-Posof and Maçka-Hamsiköy populations.

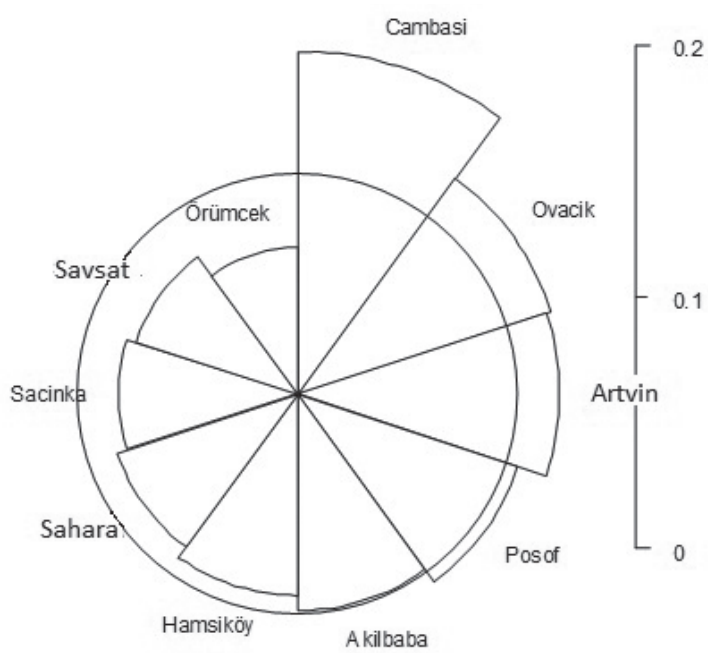

Figure 3. Genetic differentiation related to the populations Slika 3. Genetska diferencijacija populacija 


\section{DISCUSSION AND CONCLUSION RASPRAVA I ZAKLJUČCI}

Earlier studies on variation in morphological and genetic characters have revealed the existence of considerable variation in oriental spruce (Atalay 1984; Goncharenko et al. 1996; Turna and Yahyaoğlu 2002; Turna 2004; Temel 2010). However, there is not much study showing genetic variation by using different enzyme systems to represent the natural distribution areas of this species.

Expected and observed heterozygosities allow the most accurate estimation of the genetic variation level within populations. According to the results of the present study, it was determined that the mean observed heterozygosity $\left(\mathrm{H}_{\mathrm{o}}\right)$ value was 0.154 . In a study conducted in 12 populations using two enzyme system for $P$. orientalis in Turkey, mean expected heterozygosity per population varied from 0.128 to 0.463 , with an average of 0.280 (Turna and Yahyaoğlu 2002). Serbian spruce (Picea omorika (Panc.) Purk.), having isolated distribution range like Picea orientalis, exhibited considerable variation in terms of both heterozygosity and gene diversity among populations. Observed heterozygosities ranged from 0.018 to 0.132 , whereas expected heterozygosities varied from 0.017 to 0.096 (Ballian et al. 2006). In a research made in the populations of Picea abies, observed heterozygosity ranged from 0.136 to 0.173 , with the mean of 0.158 in Carpathian region (Korshikov and Privalikhin 2007). Another study was conducted for Norway spruce distributed in Romania. According to this, expected heterozygosity $\left(\mathrm{H}_{\mathrm{e}}=0.115\right)$ was similar to the average value obtained in 70 populations from Europe natural range of the species (Lagercrantz and Ryman, 1990; Radu et al. 2014). While expected heterozygosity was 0.156 in a study conducted in the same species in Poland, expected and observed heterozygosity were determined as 0.186 and 0.185 , respectively, in a study conducted in Latvia (Goncharenko et al. 1995; Lewandowski and Burczyk 2002). Ballian et al. (2009) stated that observed heterozygosity in the populations of P. abies ranged from 0.19 to 0.22 in Slovenia and Bosnia and Herzegovina, on the extreme sites (for realistic data from Bosnia and Herzegovina, the author should consult the proposed literature). It is clearly understandable that there are similarities between the previous researches related to Picea genus and the present study. Unlike this situation, Gömöry (1992), in the study for P. abies in Poland, reported that expected and observed heterozygosity were 0.306 and 0.275 , respectively. In this study for oriental spruce, the grand mean of $\mathrm{H}_{\mathrm{o}}=0.154$ showed the smaller average heterozygosity than the reported studies for Norway spruce including $\mathrm{H}_{\mathrm{o}}=22.6 \%$ (Müller-Starck 1995), $\mathrm{H}_{\mathrm{o}}=25.2 \%$ (Konnert and Franke 1990; Konnert 1991), $\mathrm{H}_{\mathrm{o}}=22.2 \%$ (Löchelt and Franke 1993). In addition, observed heterozygosity was found as $14.7 \%$ in a study in Austria (Geburek 1999).
The number of alleles per locus $\left(A_{L}=1.74\right)$ obtained from the present study conducted for Picea orientalis was higher than other Norway spruce populations studied in Romanian Carpathians region $\left(\mathrm{A}_{\mathrm{L}}=1.21\right)$ (Radu et al. 2014). While $A_{L}$ value (1.58) obtained for Picea abies in another study (Lagercrantz and Ryman 1990) was close to the value that we obtained in our study, $\mathrm{A}_{\mathrm{L}}=1.45$ value obtained for Picea asperata was lower (Luo et al. 2005). Krutovskii and Bergmann (1995) found that this value occurred as 2.4 for Picea obovata in Kazakhstan and Siberia. In different studies made for P. abies, the number of alleles per locus was determined as 2.17 in Poland (Lewandowski and Burczyk 2002), as 2.2 in Austria (Geburek 1999), as 2.26 in Latvia (Goncharenko et al. 1995), as 2.50, 2.80, 2.90, 2.90 and 2.80 in Germany, Sweden, Byelorussia, Ukraine and Russia, respectively (Krutovskii and Bergmann 1995), as 2.59-2.71 in the Mountain of Igman (Ballian et al. 2007a), as 2.06 and 3.38 in Slovenia and Bosnia and Herzegovina, respectively (Ballian et al. 2009), and as 3.55 in Ukrainian Carpathians (Korshikov and Privalikhin 2007). As can be seen from the results, these values are higher than the number of alleles per locus obtained for $P$. orientalis in this study.

According to results of a study conducted for P. asperata in China, the sampled populations were characterized by low genetic diversity (mean $\mathrm{H}_{e}=0.096$ ) and a low level of inbreeding (mean Fis=0.005). In addition, the expected heterozygosities $\left(\mathrm{H}_{\mathrm{e}}\right)$ and observed heterozygosities $\left(\mathrm{H}_{\mathrm{o}}\right)$ were relatively low and ranged from 0.066 to 0.131 , and from 0.059 to 0.141 , with an average of 0.096 and 0.094 , respectively (Luo et al. 2005). In a study carried out for P. abies in Poland, a relatively low allozyme differentiation was determined among populations from north-eastern and southern Poland (mean genetic distance $\mathrm{D}=0.005$ ). According to the results, historical events and extensive gene flow played a significant role in the distribution of the observed allozyme differentiation of the species in Poland (Lewandowski and Burczyk 2002). In another study conducted by Geburek (1999) regarding P. abies, while the genetic diversity was 1.18 in Austria, this varied from 1.23 to 1.28 in Slovenia and Bosnia and Herzegovina, on the extreme sites. (for realistic data from Bosnia and Herzegovina, the author should consult the proposed literature) In the study conducted in Latvia, the genetic distance among the populations ranged between 0.003 and 0.012 . When the results of the study were evaluated, there were a very low differentiation and close genetic relationship among the populations in Latvian (Goncharenko et al. 1995).

While the highest value in terms of $\mathrm{V}_{\text {gam }}(18.077)$ was determined in Provenance No. 2 (Torul-Örümcek), the lowest one was obtained as 8.656 in Provenance No. 4 (OrduÇambaş1). The arithmetic grand mean related to this value was 12.877 . Oriental spruce has a local and limited natural distribution for both Turkey and the world. Therefore, ge- 
netic variation of this species is of great importance. In this study, Torul-Örümcek population having the highest $\mathrm{V}_{\text {gam }}$ value is located in backward section of Eastern Black Sea Region in Turkey. In the genetic diversity studies concerning oriental spruce and the other species, this area is presented as a region with high variation (Temel 2010; Velioğlu et al. 2012). Ordu-Çambaşı population having the lowest $\mathrm{V}_{\text {gam }}$ value is located in Central Black Sea Region in Turkey. In the scope of the study, three different groups revealed among the populations. Similarly to this study, Turna (2004) found that Ordu-Çambaşı region was located in a group being different from the other regions. It should be added that Torul-Örümcek population stands out with its genetic variation. In-situ and ex-situ conservation of these populations, located in natural distribution area of oriental spruce and having high genetic variation, is important. In Turkey, rough geographical structure, different climate types and soil characteristics encourage to create local breeds even in short distances (Iș1k 1988; Kaya 1989). Optimal protection of a species and its genes can take place in its natural habitat.

At the beginning of breeding programs, genetic diversity and variation studies are emphasized within species. If there is not enough genetic diversity between trees and populations in terms of desirable characters in tree species, and the inheritance values of tree characters are too low, the expected benefits from breeding will not occur (Işık 1994; Güney 2005).

In terms of climate change, genetic diversity is one of the most important factors that can contribute to the adaptation of species (Thompson et al. 2009; Radu et al. 2014). Characterization and conservation of genetic variation is significant for tree populations exposed to a wide range of abiotic and biotic stress factors in time and space. Since future environmental stress factors together with the global warming will increase, the adaptability of tree populations becomes even more important. The situation of genetic variation in present and future generations will determine this adaptation (Müller 1995).

The great number of rare alleles being evident in forest tree populations and having a large potential to create genetic diversity should be preserved. Rare alleles considerably increase the genetic variability and thus the ability of adaptation and survival of long lived carrier species of complex forest ecosystems under highly variable environmental conditions. Local populations which are reserves against genetic erosion and genetic pollution should be protected to be used as genetic sources in future (Müller 1995). On the other hand, Ballian et al. (2007b) stated that it would be necessary to establish a dense network of gene banks in situ and ex situ, and to preserve the genetic diversity within populations in order to preserve the natural genetic resources of spruce in Bosnia and Herzegovina.
The diversity of gene, species and ecosystem levels for sustainable development should be protected and maintained. Genetic diversity provides wide adaptability and evolutionary potential to the species carrying those genes in order to adapt changing conditions and environments. Therefore, the components of biodiversity must first be protected, then researched and learned, and finally, they should be used in accordance with the principles of sustainability within the framework of the knowledge and understanding derived from them.

\section{ACKNOWLEDGMENTS}

\section{ZAHVALA}

This study was supported by the DAAD (German Academic Exchange Service).

\section{REFERENCES}

\section{LITERATURA}

- Atalay, I., 1984: Regioning of the seed transfer of Oriental spruce (Picea orientalis L.) in Turkey. Forest General Directorate, Forest Tree Seeds and Breeding Research Directorate, Publication No. 2, Ankara, pp. 67.

- Avise, JC., 1994: Molecular markers, natural history and evolution. Chapman and Hall, New York.

- Ballian, D., R. Longauer, T. Mikić, L. Paule, D. Kajba, D. Gömöry, 2006: Genetic structure of a rare European conifer, Serbian spruce (Picea omorika (Panč.) Purk.). Plant Systematics and Evolution 260(1): 53-63.

- Ballian, D., F. Bogunić, M. Konnert, H. Kraigher, M. Pučko, G. Božič, 2007a: Genetička diferenciranost subpopulacija obične smreke (Picea abies (L.) Karst.) na planini Igman. Šumarski list 1/2: 13-23.

- Ballian, D., F. Bogunić, G. Božic, 2007b: Genetička varijabilnost obične smreke (Picea abies /L./ H. Karst.) u bosanskom dijelu Dinarida. Šumarski list 6(7): 237-246.

- Ballian, D., F. Bogunić, G. Božic, 2009: Genetic structure of Picea abies populations growing on extreme sites as revealed by isoenzyme markers: a case study from Slovenia and Bosnia and Herzegovina, Dendrobiology 61: 137-144.

- Conkle, MT., 1979: Isozyme variation and linkage of allozymes in six conifer species, in: Conkle, MT. (Ed) Proceedings of the Symposium on Isozymes of North AmericanForest Trees and Forest Insects, Gen. Tech. Rep. PSW-48, USDA Forest Service, Berkeley, California, 11-17.

- Crawford, DJ., 1989: Enzyme electrophoresis and plant systematics. In: D. E. Soltis, P. S. Soltis [eds.]: Isozymes in plant biology, Dioscorides Press, Portland, Oregon, USA, pp. 146-164.

- Feret, PP., F. Bergmann, 1976: Gel electrophoresis of proteins and enzymes, in Miksche, JP. (Ed) Modern Methods in Forest Genetics, Springer, Berlin, Heidelberg, 49-77.

- Geburek, T., 1999: Genetic Variation of Norway Spruce (Picea abies [L.] Karst.) Populations In Austria, III.Macrospatial Allozyme Patterns Of High Elevation Populations, Forest Genetics 6(3): 201-211. 
- Gillet, EM., 1998: GSED: Genetic Structure from Electrophoresis Data, Version 1.1 User's Manual, Institut für Forestgenetik und Forstpflanzenzüchtung, Universitat Göttingen, Germany.

- Gömöry, D., 1992: Effect of stand origin on the genetic diversity of Norway spruce (Picea abies Karst.) populations. Forest Ecology and Management 54: 215-223.

- Goncharenko, G., IV. Zadeika, JJ. Birgelis, 1995: Genetic structure, diversity and differentiation of Norway spruce (Picea abies (L.) Karst. ) in natural populations of Latvia, Forest Ecology and Management 72(3): 1-38.

- Goncharenk, GG., AE. Silin, AE. Padutov, VE. Padutov, 1996: Genetic resources of pine, spruce and fir species in the former Soviet Union: analysis of their genepools, phylogenetic relationships and genome organization. in Goncharenko GG, Turok J, Gass T, Paule L (Eds.): Sustainable forest genetic resources programmes in the Newly Independent States of the former USSR. Proceedings workshop Sept. 23-26, 1996, Belovezha, Belarus, pp. 84-101.

- Gregorius, HR., 1978: The concept of genetic diversity and its formal relationship to heterozygosity and genetic distance. Math. Bioscience 41: 253-271.

- Gregorius, HR., 1987: The relationship between the concepts of genetic diversity and differentiation. Theor. Appl. Genetics 74: 397-401.

- Gregorius, HR., J. Krauhausen, G. Müller-Starck, 1986: Spatial and temporal genetic differentiation among the seed in a stand of Fagus sylvatica L.. Heredity 57: 255-262.

- Güney, D., İ. Turna, 2005: Ormancılıkta Ağaç Islahı ve Gen Kaynaklarının Korunmasının Önemi, T.C. Çevre ve Orman Bakanlı̆̆ı, 1. Çevre ve Ormancılık Şurası, 2. cilt, Antalya.

- Hamrick, JL., MJV. Godt, SL. Sherman-Broyles, 1992: Factors influencing levels of genetic diversity in woody plant species. New Forest 6(1-4): 95-124.

- Işık, F., 1994: Kızılçam (Pinus brutia Ten.) populasyonlarında denizden uzaklık ve yüksekliğe göre değișen genetik çeşitlilik, Batı Akdeniz Araştırma Müdürlüğü Yayınları, Antalya (in Turkish).

- Işık, K., 1988: Orman Ağacı Türlerimizde Lokal Irkların Önemi ve Genetik Kirlenme Sorunları, Orman Mühendisliği Dergisi, 25(11): 25-30 (in Turkish).

- Kaya, Z., 1989: Genetik Uyumluluk, Tohum Kaynağı ve Tohum Transferi, Fidan Dergisi, OGM Meslek Memurları Derneği Yayın Organı, 17: 3-8 (in Turkish).

- Kayacık, H., 1980: Doğu Ladini (Picea orientalis L.)'ni coğrafik yayılışı. Review of the Faculty of Forestry, University of İstanbul, series B, 2: 25-32.

- Konnert, M., A. Franke, 1990: Die Fichte (Picea abies (L.) Karst.) im Schwarzwald: Genetische Differenzierung von Bestanden. Allg. Forst- u. J.-Ztg. 162: 100-106.

- Konnert, M., 1991: Die Fichte (Picea abies (L.) Karst.) im Schwarzwald: Genetische Variation und Korrelationen. Forstw. Cbl. 110: 84-94.

- Korshikov, II., SN. Privalikhin, 2007: Genetic Structure of Populations of Norway Spruce (Picea abies (L.) Karst.) from Ukrainian Carpathians. Russian Journal of Genetics 43(12): 1364-1372.

- Krutovskii, KV., F. Bergmann, 1995: Introgressive hybridization and phylogenetic relationships between Norway, Picea abies (L.) Karst., and Siberian, P. obovata Ledeb., spruce species studied by isozyme loci, Heredity 74: 464-480.
- Lagercrantz, U., N. Ryman, 1990: Genetic structure of Norway spruce (Picea abies (L.) Karst.): Concordance of Morphological and Allozymic Variation.

- Lewandowski, A., J. Burczyk, 2002: Allozyme Variation of Picea abies in Poland, Scand. J. For. Res. 17: 487-494.

- Liengsiri, C., C. Piewluang, TJB. Boyle, 1990: Starch Gel Electrophoresis of Tropical Trees, A Manual, ASEAN-Canada Forest Tree Seed Centre and Petawawa National Forestry Institute, Muaklek, Saraburi, Thailand, 51.

- Löchelt, S., A. Franke, 1993: Bestimmung genetischer Merkmale von Fichten (Picea abies (L.) KARST.) mit unterschiedlich ausgepragten Schadsymptomen auf baden-württembergischen Dauer beobachtungsflachen. Allg. Forst- u. J.-Ztg. 165: 21-27.

- Luo, J., Y. Wang, H. Korpelainen, C. Li, 2005: Allozyme Variation in Natural Populations of Picea asperata, Silva Fennica 39(2): 167-176.

- Müller-Starck, G., 1995: Genetic variation in high elevated populations of Norway spruce (Picea abies (L.) Karst.) in Switzerland, Silvae Genetica 44: 5-6.

- Müller-Starck, G., F. Baradat, F. Bergmann, 1992: Genetic variation within European tree species, New Forests 6: 23-47.

- Ouborg, NJ., Y. Piquot, JM. Van Groenendael, 1999: Population genetics, molecular markers and the study of dispersal inplants.J. Ecol., 87: 551-568.

- Radu, RG., LA. Curtu, G. Spârchez, N. Şofletea, 2014: Genetic diversity of Norway spruce [Picea abies (L.) Karst.] in Romanian Carpathians, Ann. For. Res. 57:1, 19-29.

- Saatçioğlu, F., 1976: Silvikültürün Biyolojik Esasları ve Prensipleri, (Silvikültür I), İÜ Orman Fakültesi, Yayın No. 2187/222, İstanbul (in Turkish)

- Swofford, DL., RB. Selander, 1997: BIOSYS-2: A Computer Program for the Analysis of Allelic Variation in Genetics, User's Manual, Department of Genetics and Development, Univ. of Illinois at Urbana-Champaign, Urbana, Illinois, USA.

- Temel, F., 2010: Oriental spruce (Picea orientalis (L.) Link) breeding efforts III. Ulusal Karadeniz Ormancilık Kongresi, 2022 Mayıs, Cilt II, 775-779.

- Thompson, I., B. Mackey, S. McNulty, A. Mosseler, 2009: Forest resilience, biodiversity, and climate change. A Synthesis of the Biodiversity/Resilience/Stability in Forest Ecosystems. Secretariat of the Convention on Biological Diversity, Montreal. Technical Deries no. 43, 67.

- Turna, İ., 2004: Variation of morphological characters of Oriental spruce (Picea orientalis) in Turkey, Biologia, Bratislava, 59:4,519-526

- Turna, İ., Z. Yahyaoğlu, 2002: Allozyme variation in some populations of Oriental spruce (Picea orientalis) in Turkey, $\mathrm{Pb}$. Univ. Res. Bull. 52: 119-125.

- Üçler, AÖ., A. Demirci, H. Yavuz, Z. Yucesan, E. Oktan, AU. Gül, 2001: Alpin Zona Yakın Saf Doğu Ladini Ormanlarının Meşcere Kuruluşlarıyla Fonksiyonel Yapılarının Tespiti ve Silvikültürel Öneriler. TOGTAG TARP-2215, Trabzon (in Turkish): TÜBİTAK

- Üçler, AÖ., C. Acar, Z. Yücesan, E. Oktan, 2018: Effect of thermal pretreatment on germination of seeds from different provenances of subalpine oriental spruce (Picea orientalis (L.) Link.) forest in Turkey, Journal of Sustainable Forestry 37:3, 302-315.

- Velioğlu, E., Y. Tayanç, B. Çengel, G. Kandemir, 2012: Genetic Variability of Seed Characteristics of Abies Populations from 
Turkey, Kastamonu Univ., Journal of Forestry Faculty, Special Issue.

- Vicario, F., GG. Vendramin, P. Rossi, P. Liò, R. Giannini, 1995 : Allozyme, chloroplast DNA and RAPD markers for determining genetic relationships between Abies alba and the relict population of Abies nebrodensis. Theoretical and Applied Genetics 90:7-8, 1012-1018.
- Wright, S., 1978: Evolution and the Genetics of Populations. Vol. 4: Variability within and among Natural Populations. Chicago: University of Chicago Press.

- Yahyaoğlu, Z., A. Demirci, M. Genç, 1991: A Relict (Paleoendemic) Species: Oriental Spruce (Picea orientalis (L.) Link.). [In Turkish], 1. Uluslararası Çevre Koruma Sempozyumu, Cilt I, 254-263, Ege Üniversitesi, İzmir, Türkiye.

\section{SAŽETAK}

Za razumijevanje genetske strukture populacija šumskog drveća potrebno je poznavati genetsku varijabilnost. Razvoj izoenzimske tehnike olakšao je određivanje genetske strukture populacija u području rasprostranjenja vrsta. Određivanjem genetske strukture i varijabilnosti Picea orientalis (L.) Link, koja je u svijetu ograničena na manje područje, transfer trenutne genetske strukture na buduće generacije putem održivog gospodarenja šumama važan je za osiguravanje kontinuiteta vrste. U ovom istraživanju određene su genetske različitosti i sličnosti za populacije $P$. orientalis u odabranim populacijama (Artvin, Torul-Örümcek, Tirebolu-Akılbaba, Ordu-Çambaşı, Artvin-Şavşat, Ardanuç-Ovacık, ŞavşatSahara, Artvin-Saçinka, Ardahan-Posof an Maçka-Hamsiköy) Turske. Korišteno je 10 genskih lokusa $\mathrm{u}$ različitim enzimskim sustavima, a određena je genetska varijabilnost, vrijednost heterozigotnost $\left(\mathrm{H}_{\mathrm{o}}\right)$, broj alela po lokusu $\left(\mathrm{A}_{\mathrm{L}}\right)$, genetski diverzitet $(\mathrm{v})$, intrapopulacijska diferencijacija $\left(\mathrm{d}_{\mathrm{T}}\right)$, multilokusna raznolikost $\left(\mathrm{V}_{\text {gam }}\right)$ te diferencijacija među populacijama $(\mathrm{Dj})$. Za promatranu heterozigotnost, broj alela po lokusu i genetski diverzitet dobivena je središnja vrijednost od 0.154, 1.74 i 1.719. Nadalje, kod razmatranja genetskog diverziteta, pojavile su se tri različite skupine u smislu odabranih populacija. S obzirom da je populacija Torul-Örümcek pokazala relativno više vrijednosti u odnosu na ostale populacije, ova populacija je vrlo važna za održivost genetskih izvora kavkaske smreke .

KLJUČNE RIJEČI: genetski diverzitet, očuvanje, izoenzimi, Picea orientalis 